\title{
NEGRO NA AMAZÔNIA: \\ RECUPERANDO SUA HISTÓRIA
}

\author{
SAMPAIO, Patrícia M. (org.). O fim do silêncio - presença negra na \\ Amazônia. Belém: Açaí / CNPq, 2011. 298 p.
}

$P$ artindo de um amplo acervo de fontes, escritas e orais, a presente coletânea alarga o campo de reflexão, num olhar multidisciplinar, sobre história, memória e práticas culturais ainda pouco visitadas - a presença negra na região amazônica, em especial no estado do Amazonas. Os textos aqui reunidos resultam de investigações de um grupo de pesquisa, além do desdobramento de estudos realizados no âmbito de vários programas de pós-graduação, em especial da UFAM, que possibilitam olhar com mais acuidade para uma região que pode parecer - mas não é “ homogênea em sua paisagem e sua cultura. Este livro nos dá a conhecer uma destas significativas diferenças, ao tratar de experiências de negros escravos, livres e libertos, de suas representações culturais e identitárias. História a partir de vestígios recuperados que podem vencer o esquecimento, o ocultamento, o silêncio.

Ante o estudo de temáticas que abordam a presença negra na Amazô- nia, não raro o pesquisador é indagado: e ali houve escravidão?! O tom surpreso da pergunta revela não apenas um desconhecimento da história daquela região, mas também põe em relevo esta ausência na historiografia brasileira sobre o escravismo, que tem privilegiado as áreas de plantation e de mineração, onde a mão de obra escrava africana foi hegemônica. Um questionamento que revela a representação de uma Amazônia extrativista; das drogas do sertão coletadas pelos nativos e caboclos. Essa percepção de um espaço de cultura marcadamente indígena, fez com que a escravidão e a cultura africanas se deslocassem a um plano menor, constituindo um vazio na historiografia regional, o que fica mais evidente ao se buscar estudos sobre as comunidades negras, quilombolas ou não, que se constituíram ao longo da história. ${ }^{1}$

Eurípedes A. Funes, "Nasci nas matas nunca tive senhor": história e memória dos mocambos do Baixo Amazona (Tese de doutorado, Universidade de São Paulo, 1995). 
Hoje este cenário historiográfico apresenta outro desenho.

A presente obra se insere neste novo contexto e soma-se àquelas que abordaram com pertinência a presença negra na Amazônia brasileira, em especial no Pará, onde Vicente Salles, a partir de documentação inédita, escreveu uma obra impar, $O$ negro no Pará, publicada em 1971. Por ser um estudo abrangente, algumas questões foram pouco analisadas, mapeando, no entanto, sinais significativos para futuras pesquisas sobre o mundo criado pelos negros, escravos, libertos e livres naquela região. É, sem dúvida, um marco na historiografia regional sobre essa temática; leitura obrigatória para se começar a entender a presença da escravidão e da cultura negra na Amazônia.

Com este livro não é diferente. Uma história que remonta às primeiras décadas da colonização, quando já era possível encontrar, em 1637, entre os poucos moradores de Belém algumas dezenas de escravos. Neste mesmo ano, a expedição comandada por Pedro Teixeira, que subiu o rio Amazonas, estava composta por alguns soldados, centenas de nativos e escravos africanos.

Partindo de um balanço historiográfico e da análise de um corpus documental, em especial para a província de São José do Rio Negro, Patrícia Sampaio, no capítulo "Escravos e escravidão africana na Amazô- nia", discute a inserção do africano no mercado de trabalho. Um processo lento, resultado de apelos contínuos das autoridades locais pressionadas pelos colonos frente ao impedimento do emprego da mão de obra indígena, em razão da ação contrária da Igreja e da legislação governamental, processo que ademais enfrentou dificuldades devidas à economia ali desenvolvida, o extrativismo. Somava-se a isso o limitado poder aquisitivo dos colonos, já que essa atividade era, e é, flutuante, sazonal, sem alta rentabilidade e, em decorrência, resulta uma circulação monetária acanhada e a inexistência de bens que pudessem ser dados em hipoteca na aquisição de negros escravizados

As representações mais correntes sobre o mundo do escravo são marcadas pela despersonalização do indivíduo, pela visão do sofrimento e do desencanto, ou a polarização entre violência e rebeldia, ou seja, não se distingue na vida dos escravos sentimentos, família e relações sociais que escapem ao controle do senhor. No entanto, é necessário não esquecer a sua condição humana e que, como tal, viveram e sobreviveram à ordem escravista. Nesse sentido, eram passíveis de paixão, ódio, desejos, compreensão, e capazes de entender o momento de agir contra sua condição, negociar, ter reações explícitas, ou não, contra a ordem escravista. Portanto, tinham consciência do sis- 
tema em que viviam, e buscavam espaços em que pudessem legitimar suas ações e garantir direitos.

Assim, sabendo olhar, e querendo ver, se percebe que no seu cotidiano os escravos exploraram seus momentos de autonomia, relativa é claro, e fizeram destes um direito. $\mathrm{O}$ casamento (no caso da Amazônia muito frequente entre negros africanos e negros da terra), as relações sexuais, o nascimento de um filho foram expressões significativas desses momentos. Circular por propriedades vizinhas não constituía novidade para os cativos da região, pois eram frequentes os casos em que eles, a mando de seus senhores, se deslocavam a longas distâncias - aliás, circular pelos rios, lagos e igarapés era típico de um escravo pescador, ou condutor de embarcação, por exemplo.

Esses aspectos não significam, de forma alguma, que houve uma aceitação tácita do escravo à sua condição social, nem uma benevolência explícita, ou mesmo implícita, dos senhores. A luta de classes não deixava de existir. Havia várias formas de fazê-la e era no cotidiano que o escravo construía a sua contra-ordem es-cravista. Experiências tais são destacadas por Provino Pozza Neto, ao analisar as alforrias, onerosas ou não, na província do Amazonas. $\mathrm{O}$ autor sugere que o escravo tem clareza da lógica da dominação e cria uma série de mecanismos capazes de lhe garantir espaços e de questionar os mecanismos de controle inerentes à escravidão. As fontes documentais têm demonstrado que o escravo, mesmo limitado por um estatuto social e outro legal, conseguia espaço para negociar, manifestar-se como agente histórico. Negociar a alforria, por exemplo. Tinha queixas do destino que lhe havia sido imposto e por isso buscava formas de superar adversidades, pois "é nessa micropolítica que o escravo tenta fazer a vida e, portanto, a história."2

E por que fugiam? Bastaria dizer: porque eram escravos. É deste assunto que trata o capítulo de Ygor Olinto Cavalcante, “'Fugindo, ainda que sem motivo': escravidão, liberdade e fugas escravas no Amazonas imperial". Há uma série de razões decorrentes da sua condição, que levaram os cativos a apelar para a fuga. Estava na relação senhor/escravo uma das razões da fuga, mais do que no ato de sedução de "contrabandistas" ou de hábeis sedutores. Se o escravo conquistasse no seu cotidiano garantias de autonomia de ação e movimento, tendo a possibilidade, mesmo mínima, de gerenciar sua vida, ele com certeza pensaria duas vezes antes de fugir. Os escravos tinham noção cla-

\footnotetext{
2 João J. Reis e Eduardo Silva. Negociação e conflito: a resistência negra no Brasil escravista, São Paulo: Companhia das Letras, 1989, p. 21
} 
ra do contexto e se valiam da conjuntura para forçar negociações, conseguir mais autonomia e flexibilidade de ação den-tro do próprio sistema escravista, tendo a fuga como principal arma engatilhada contra as ameaças às suas conquistas, ainda que precárias.

Aproveitando-se da complexidade da região, das longas distâncias e dos rios que constituíam caminhos naturais para a fuga, os escravos, ao se evadirem das propriedades de seus senhores, tinham como opção ir para outros centros urbanos ou se embrenharem nas matas. Nesse sentido, havia a possibilidade de grande mobilidade espacial para os cativos em fuga, que procuravam passar por libertos, misturando-se às camadas populares um tanto matizadas, onde um mulato podia passar por um tapuia, um curiboca, por um cafuzo. Assim, a qualidade da cor se diluía, quebrando um elemento a mais de identidade do escravo fujão, já que costumava tam-bém trocar de nome. Outra saída encontrada pelo escravo em fuga era valer-se de instrumentos legais que garantissem a ex-cativos o status de livre, e a partir daí encontrar mecanismos para preservar a condição de liberto.

Ajustando-se como tripulantes de barcos, ou neles se escondendo, os escravos em fuga circulavam ao longo dos rios, em especial pelo Amazonas, deslocando-se com certa facilidade entre o Baixo Amazonas, e
Manaus, e vice-versa, como mostram os relatos observados nos anúncios de fuga analisados por Cavalcante. Assim, escravos fujões circulam pelos rios, igarapé e lagos da região.

Fugir, como se vê, não significava necessariamente ir diretamente para os quilombos, podiam circular pelos rios, se juntar a outros negros livres e libertos, como aqueles que chegaram ao Amazonas fugindo das secas que calcinavam o Nordeste. É o caso da comunidade negra constituída por descendentes de escravos de Sergipe que chegaram ao rio Pauni, o rio dos pretos, por volta de 1907. Através de narrativas orais, Emmanuel Almeida, no capítulo "Quilombolas no Amazonas: do rio dos pretos ao Quilombo do Tambor", adentra a história destes quilombolas, que materializam o sentido de liberdade, o direito à terra, a configuração de uma territorialidade, a afirmação de pertença e identidade.

Todavia, os espaços de autonomia não se limitavam a essas práticas. Eram buscados, também, nos folguedos religiosos. Momentos de lazer em que diferentes elementos culturais se mesclam, em que o sagrado e o profano se confundem e as manifestações se expressam através dos cantos, das danças e nos ritmos dos batuques e dos sons tirados do gambá, da marimba, da onça e da viola europeia

As festas constituíam, para os escravos, momentos de ruptura com a vida cotidiana. Oportunidade em que 
vestiam os seus melhores trajes. Geralmente as mulheres usavam vestidos bufantes e coloridos, esbanjavam sensualidade nas danças do lundu e do carimbo, ao som dos tambores. Momentos em que as relações antagônicas tornavam-se fragilizadas e em que livres e escravos faziam causa comum. O ciclo das festas natalinas era o tempo em que essas rupturas se acentuavam. Henry Bates, em 1851, presenciou dois momentos de festejos. Em Santarém, "os negros faziam uma grande apresentação semiteatral nas ruas", e na vila de Serpa, hoje Itacoatiara-AM,

à noite o povo se entregou a alegres folguedos por toda a cidade. Os negros, devotos de um santo que tinha a sua cor - São Benedito - fizeram a sua festa à parte e passaram a noite toda cantando e dançando ao compasso de um tambor comprido, chamado "gambá", e do "caracaxá".

Uma festa ao santo negro que, mesmo quando ganha o espaço urbano, como relata Jamily Sousa da Silva em "A festa de São Benedito no bairro da praça 14", mantém elementos comuns àquelas das comunidades quilombolas da região amazônica - uma festa de mastro, dança do lundu ao som dos tambores.

Valendo-se das festas religiosas, os escravos faziam devoções a seus

Henry Bates, Um naturalista no rio Amazonas. Belo Horizonte: Itatiaia, São Paulo: Edusp 1979, p. 124 e 141. santos, cantavam seus hinos e dançavam. Eram momentos em que as origens africanas se manifestavam, e novas identidades culturais se constituíam. Carimbó, lundu, boi-bumbá, marambiré, aiuê e outros folguedos se cristalizaram a partir de práticas culturais dos escravos, e hoje, como diz Vicente Salles, "a lúdica amazônica, no que tem de mais representativo, é essencialmente africana". ${ }^{4}$

As festas juninas constituíam outro ciclo festivo em que os folguedos religiosos possibilitavam alegrias aos negros. Era e é tempo do boi-bumbá, "uma estranha folia" aos olhos de viajantes do século XIX, como Henry Bates, Robert Avé-Lallemant e Sanches Frias. Um "boi" que vai marcando a calha do grande rio, uma festa de negro, lugar dos filhos de mãe Catirina e pai Francisco. Mais que um grande espetáculo televisivo, esta “estranha folia" tem sido elemento forte de uma cultura afro em terras manauaras. Danças e andanças de negros na Amazônia, como nos coloca Sérgio Ivan Gil Braga, que pergunta: por onde anda o filho de mãe Catirina? E pai Francisco, seria ele o Macunaíma de Mario de Andrade?

São cantos e danças que exprimem uma nova "estética musical". Sons, ritmos, palavras, cantos que vêm do outro lado do Atlântico, que

4 Vicente Salles, O negro no Pará. Rio de
Janeiro: FGV, Belém: UFPA, 1971, p. 186 
se materializam, se mesclam em novas formas de expressão da cultura negra, em rodas de capoeira, por exemplo, como relata Luís Carlos de Matos Bonates em "A capoeiragem baré", onde apresenta a capoeira no Amazonas, com ou sem berimbau.

O livro vai assim, dando conta de lugares específicos da vasta região e de uma população

que excluída por um processo econômico e urbanístico direcionado para entender as elites, vivia, segundo Bonates - parafraseando o escritor Milton Hatoum - em uma "zona de sombra, escondida ou muito pouca revelada".

Lugares onde capoeiras, berimbaus, gambá, carimbó, tambores, boi, sons e ritmos, antigos e novos, ecoam na terra de Ajuricaba, marcando as danças e andanças dos filhos de mãe Catirina e pai Francisco. A visibilidade afro-amazônica ganha as ruas da cidade com uma musicalidade, ritmos e danças que vêm de outros lugares, mas as letras que vêm dos becos, dos excluídos, expressam a força de uma luta. Estas experiências contemporâneas dos negros do Amazonas estão presentes no texto de Sidney Barata de Aguiar que em "Hip hop de leste a oeste de Manaus: quatro cabeças de uma hidra urbana" traz à tona história desta gente sem crônica

Tomando a literatura como fonte, Maria José Nunes Aleixo e Patrícia Sampaio fazem uma leitura cui- dadosa da obra de Ferreira de Castro. Em "Gente sem crônica definitiva: negro e mulato n'A Selva", as autoras buscam, como dizem, abrir mais uma janela "para romper o silêncio sobre a tão discutida presença do negro na Amazônia".

Ler este livro é como percorrer muitos caminhos de um passado afroamazônico a não ser esquecido e que alimenta a luta daqueles a quem direitos de cidadania têm sido negados, como informam Arlete Anchieta da Silva e Gláucia Gama no balanço que fazem de um dos programas de ação afirmativa no capítulo "Braços que remam nas águas do rio Negro rumo ao PROUNI: acadêmicos afrodescendentes do Amazonas".

Braços que remam no mesmo sentido, junto aos professores negros que nas universidades enfrentam novas formas de ver e encarar o racismo e o preconceito, que o saber acadêmico nem sempre supera, mas, ao contrário, frequentemente, cria novos estereótipos que marcam aqueles que tiveram a marca da exclusão social em suas trajetórias de vida. É este o tema de Ednailda Santos em "Identidades e trajetória de docentes negras(os) da UFAM".

O livro, como que num pacto firmado entre seus autores, expressa $o$ sentimento de que, para vencer a injustiça racial, o esquecimento precisa parar de vencer.

Eurípedes A. Funes Universidade Federal do Ceará 